\title{
Impact of Employing Dictogloss Strategy on Ninth Grade Students' Achievement in Listening Skill
}

\author{
Sondos Hani Alqararaa ${ }^{1 *}$ Dr. Mohammad Dayij Alqomoul ${ }^{2}$ \\ 1.Ain Elbaida Secondary Shool fo Girls - Ministry of Education - Jordan \\ 2.Tafila Technical University Dept. of Curricula and Instruction PO. Box: 179- Jordan
}

\begin{abstract}
The present study attempts to investigate the impact of dictogloss strategy on the achievement of the ninth graders in listening skill. It is a quasi-experimental study which uses dictogloss as an interactive strategy with ninth grade students at Ain Al-Bayda secondary school to the achievement of listening skill. The sample of the study consists of (74) female students. Experimental group: $(n=37)$ taught by dictogloss strategy and control group $(n=37)$ taught by traditional methods. To collect data, pretest and posttest are both used. Dictogloss strategy is applied on experimental group in four sessions within four weeks. The collected data is calculated and analyzed using SPSS. Results revealed that there are statistically significant differences at the level of $(\alpha=0.05)$ in the achievement mean scores of the experimental group attributed to the effect of using dictogloss strategy. However, the result rejects the null hypotheses. Researchers recommend training English language teachers to incorporate dictogloss into their instructional practices in EFL classroom, to improve the students' achievement in listening skill.
\end{abstract}

Keywords: Dictogloss, Ninth graders, Achievement, Listening skill.

DOI: $10.7176 / \mathrm{JEP} / 11-14-12$

Publication date:May $31^{\text {st }} 2020$

\section{Introduction}

The present chapter introduces the background of listening skill and dictogloss strategy. It deals with the definition and process of listening skill, the reasons which make listening important in comprehending language, originals of dictogloss, and using it in a listening context. It also presents the statement of the problem, question, hypothesis, objectives and limitations of the study.

\subsection{Background of the Study}

English is a major language in the world since it is the language of communication and technology all around the world. It is used by millions of people in social life such as: tourism, economy, technology and politics. It is also used when people from different countries are involved in communication e.g. global works, seminars, debates and meetings. Concerning language learning, English is one of the subjects stated in the school curriculum to be taught to the students. Knowledge of English is assumed to be an investment for a better career, better pays and more progressive knowledge towards achievement in personal life (Bataineh Younes, 2016).

Listening is an understanding process of speech in a second or foreign language, and it is a comprehension process which focus on the role of the individual linguistic units, for example, words, grammatical structures, and phonemes, as well as the role, the expectations of list enters e. g. background knowledge and topic, the situation and the context (Hwaider, 2017). Listening is one of the main language skills which include also reading, writing and speaking. It is important in learning other language skills. The ability of speaking, reading, writing and understanding complex skills is directly and indirectly depend upon listening (Abdel.al, 2002). Listening is considered a secondary factor for speaking fluency. Wajnryb (1990) defines listening skill as an alterative strategy for grammar instruction, and it is one of the most important language skills. More than $45 \%$ of communicating time is spent in listening, which presented how important this skill is overall language ability (Vasiljevic, 2010). Listening is considered to be a complex process that allows learners to understand spoken language. Hwaider (2017) added that listening is the most difficult skill of all language skills. The linguistic and non-linguistic problems are the reason of this difficulty. It is an invisible mental process which making it difficult to describe and understand (Carter and Nunan, 2001). However, there are two reasons which make listening important in comprehending a language:

* listening improves understanding of the spoken words. Understanding spoken language requires one skill in processing the information received. The listener has to be able to choose any information needed and connect it with his prior knowledge to have strong understanding.

* Listening becomes one typical of spoken language to reproduce in oral production. Baby need to listen for repeated words before he can produce them by himself. A foreign learner also needs to do the same as the baby does. Learner should listen to his teacher or native speaker for three times or may be more to produce the words correctly (Rixon, 1986).

Some of listening materials are not relevant or familiar to students in the most times. They may have weak background knowledge about information that they receive, or foreign countries cultures. Hence, students feel at 
loss when listening to some new text, they may misunderstand the meaning of the material or they sometimes cannot understand it (Adam, 2013).

In second language teaching, dictation has a long history in literacy education. The teacher reads a passage slowly and repeatedly in the standard procedure of dictation. Students write exactly what they hear. Traditional dictation in this form has been criticized as mechanical form of literacy and rote learning method in which students copy the text that the teacher reads without doing anything. Conventionally, listening skills have been taught alone or it is sometimes mixed with speaking tasks (Jacobs, and Small, 2003).

Dictogloss is an interactive or communicative method which supports cooperative learning and can help in the development of listening skills of both teachers and students. Dissimilar in the traditional method of dictation, in dictogloss only the idea of the text is expected to be presented by the students (Daura, 2013).

The idea of dictogloss as a cooperative strategy was first stated by Wajnryb (1990). Dictogloss consists of an improved type of dictation that makes students working collaboratively to rebuild a passage that they listen to. It is a dictation activity in classroom which contains these stages: students listen to the passage, they write the key words and main ideas then, they work in groups to create a reconstructed version of the text (Vasiljevic, 2010). Dictogloss strategy carries traditional dictation procedure and objective, but when it is contrasted with it, the learners are not permitted to paraphrasing and taking down notes (Gallego, 2014). The advocators of dictogloss method pointed out that it is a system of activity and multiple skills. Writing and speaking and learners practice listening depend on their knowledge of syntactic, semantic and dialogue systems of target language to complete the task. Listening comprehension or students' note-taking skills improvements are seen as producing of the method rather than its objectives (Vasiljevic, 2010).

Dictogloss is different from traditional dictation, which is simply defined as an activity in which students write down what the teacher reads to them. They write their own sentences depending on their own understanding. Dictation, as an instructional or testing technique is highly problematic. Generally, dictation has alternated between three views: as an ineffectual measure since the text is completely dictated to the students without any activity, as an effective measure when it testing whole language ability rather than isolated language components and as an instructional but not a testing measure (Bataineh and Younes, 2016). Using dictogloss in a listening context, Buck, (2001) states that listening needs using of both systematic and schematic knowledge in order to understand the speech. The listener must have an essential knowledge of the world. Initially designing of listening activities should give the learner practice in identifying correctly different sounds, intonation patterns and combination of sounds. Meaning based activities become more important as learner's proficiency increasing. Most of information is not stated and the listener must focus on the surface information to see other meanings such as intentions of speaker or his attitude towards a topic, and relating utterances to other social and situational contexts. Dictogloss listening procedure falls into the first category. It has different steps and objectives from the traditional dictation that students recreate a spoken text word for word. In dictogloss, learners are expected to remember the idea of the short text, and then write their own linguistic and grammatical knowledge to form a meaningful text.

\subsection{Statement of the Study}

Some students have to fight the psychological suggestion that they could not understand spoken English when they are face to face with English native speakers. Especially their listening in a dictation class, researchers felt that dictation is teacher-centered writing activity with no real input from the student, and it is an unrealistic activity. It is "word by word" and at an artificial step in listening comprehension. In real life, we often have to write down what someone says, although admittedly not necessarily literal, and the real listening is not really "word by word" but "phrase by phrase". Students should be able to reproduce a text in any language; it is actually a highly implausible proposition. Even in their own language, recreating a text accurately from the spoken word requires concentration to the thoughts of the listener. In this study, the researchers use dictogloss which is distinct from traditional dictation, and simply defined it as an activity in which students write down what they listen to by the teacher as a teaching strategy of dictation "phrase by phrase" to try improve the listening skills of ninth grade students.

A huge number of students believe that listening is a most difficult skill and they start to fear when they see a CD player or hear the word listening. From the researchers' point of view, the main problem could be the lack of control of the speaker's speed of speech. Further, this problem is connected with listening repetition as listeners cannot always make the speaker repeat what they have listened to. However, the factors that make difficulties for the students are: difficulty in identifying the communicative purpose in the listening material, difficulty of finding the main idea in the material, and difficulty of finding specific information in the material they listened to.

\subsection{Study Question}

The present study attempts to answer the following question:

Are there any statistically significant differences at the level of $(\alpha=0.05)$ in the achievement mean scores of ninth graders in the experimental and control groups on listening skill tests attributed to the effect of dictogloss strategy? 


\subsection{Study Hypothesis}

The study examines the following null hypothesis:

There are no statistically significant differences at the level of $(\alpha=0.05)$ in the achievement mean scores of ninth graders in the experimental and control groups on listening skills tests attributed to the effect of dictogloss strategy.

\subsection{Study Significance}

The study may benefit learners in the studies of teaching English skills; it may build a bridge between different language skills and promotes attractive, collaborative learning in the classroom based on dictogloss strategy. It may also contribute to encourage officials in the Ministry of Education to produce new strategies to improve the skills of second language learning.

\subsection{Study Objective}

The study aims at examining the effect of dictogloss as an effective strategy for developing the students' achievement on tests of listening skill in the Jordanian schools.

\subsection{Definition of Terms}

- Listening skill: is a process of understanding language by the sense of hearing.

- Dictogloss strategy: is a classroom dictation activity where learners listen to a passage, note down key words, and then work together to create a reconstructed version of the text.

- Ninth graders: students who study English for nine years at school in Jordan. Their ages are: 14-15 years.

\subsection{Study Limitations}

* The study was restricted to ninth graders in Tafila Directorate of Education in Jordan.

* The experiment was implemented in the second semester of the academic year 2018- 2019.

* The study instrument was constructed by the researchers.

\section{Literature Review}

In this chapter the researchers revise some of the views, ideas and previous studies that encompass the subject of the present study.

\subsection{Listening-A Macro Skill in Language Learning}

Listening has an important place in learning as it is one of the four major skills in language acquisition. Even though, the other skills such as reading, speaking and writing are essential to develop language proficiency, listening contributes primarily for language capability. Listening awakens awareness of the language as it is an agreeable skill that first develops in a human being (Buck, 2001).

Learning to listen to the target language improves language ability. The sound, rhythm, intonation, and stress of the language can only be perfectly adapted through listening. To understand the differences in a particular language, one must be able to listen. As we get to understand spoken language by listening, it is easier to improve the other skills and gain confidence. Other than being the primary form of communication, listening helps the language learner to understand the beauty of the language. Especially in terms of communicative language teaching, it is said that the basis for communicative competence is listening as it provides the aural input and enables learners to interact in spoken communication and consequently language learning largely depends on listening. Thus listening forms the physical basis for the complete language proficiency (Renukadevi, 2014).

\subsection{Importance of Listening in Communicative Language Teaching}

Listening is considered to be most significant part of communication as it is central in offering an essential and meaningful response, especially in learning a language for communicative purpose. Listening plays a main role, when it helps the language learner to acquire word stress, pronunciation, syntax, and vocabulary. The comprehension of messages conveyed can be based only on tone of voice, pitch and accent; it is possible when we listen. Learning simply cannot get any improvement without understanding input appropriately (Taheri and Taki 2017).

There is no communication can be achieved without listening skill. Also, all studies conducted regarding the acquisition of language skills has proved that when people communicate, people gain $45 \%$ of language competence from listening, 30\% from speaking, 15\% from reading and 10\% from writing. Listening has to be considered a language forerunner with the highest percentage of involvement in the exchange of information in effective communication. Unlike the other language skills, listening is much difficult by the learners, as it has all its interrelated sub skills such as receiving, understanding, remembering, evaluating, and responding. But with the oncoming of communicative language-teaching and the focus on proficiency, listening learning and teaching started to receive more attention (Cross, 1998). 


\subsection{Strategies for Effective Teaching of Listening}

Listening strategies are activities that contribute directly to receive the listening input. In teaching listening skills, the language learners are facilitated in getting adjusted to their listening behavior to deal with types of input, variety of situations, and listening purposes, so a number of listening strategies have been drafted to match with every different listening situation. Listening strategies can be classified as:

a. Top-down strategies: Top-down strategies help the listener to interpret the ideas he has listened to, and they are listener based; the listener relies on the listening context, the text type, the background knowledge of the topic, and the language. Top-down strategies are for: listening for the main idea, predicting, drawing inference, and summarizing.

b. Bottom-up strategies: In bottom-up strategies the listeners use linguistic knowledge to understand information of the text. Bottom-up strategies are to: concentrate on specific details while listening and recognize word-order patterns.

c. Metacognitive strategies : Metacognitive strategies are used by strategic listeners, because listening comprehension is not constrained either to top-down or bottom-up processing, but it should be an interactive, interpretive process where listeners apply both their linguistic knowledge and prior knowledge in the same time to understanding messages, to plan, monitor, and evaluate their listening. Using metacognitive strategies activates learner's thinking and leads to improve their performance in teaching in general (Anderson, 2002).

The metacognitive strategies make the learning more effective, they can maximize the information received and this helps to improve learners listening skills. The metacognitive strategies train the language learner to deal with the demands of listening (Mendelsohn, 1998).

\subsection{Metacognitive Strategies and Dictogloss}

Metacognitive strategies are concerned with trying to plan, check, monitor, select, revise, and evaluate, student's learning. Terms of metacognitive awareness of listening strategies is defined in five factors: problem solving, planning-evaluation, mental translation, person knowledge, and directed attention. Scholars urge that metacognitive strategies be a part of instruction in teaching listening comprehension. It is assumed that metacognitive instruction can raise learners' awareness of their listening and develops learners' ability to use appropriate strategies. Dictogloss is a type of form-focused task which provides a meaning-focused context to raise learners' awareness of use of the target linguistic features. Dictogloss is an effective pedagogical task, because it is a piece of classroom work that involves learners in comprehending, manipulating, producing or interacting in the target language while their attention is focused on mobilizing their grammatical knowledge in order to convey meaning. It provides a useful bridge between bottom-up and top-down understanding. The dictogloss strategy can have a positive impact on the improvement of listening comprehension of EFL learners. It can also be claimed that dictogloss has a positive influence on the learners' choice of metacognitive strategies, which eventually improves learners' listening comprehension (Taheri and Taki 2017).

\subsection{Dictation and Listening Skill}

Dictation is an active bottom-up approach for improving second language listening skill. It is a good task to learn phonological features and to identify constituent structure, which is an important skill in the parsing stage. It also helps learners' comprehension by paying more attention to content words that convey meaning, especially for lower proficiency learners. The practice of listening out for key words seems to be justified by providing the following implications: In the early stages of listening development, learners should be asked to build a general meaning representation on the basis of the more important content words in the text. Listening competence improves teachers moving on from meanings to forms which can be applied to teaching listening (Kurita, 2012).

\subsection{Definition of Dictogloss}

The term "dictogloss" is derived from the 'dictation' or 'dicto' which means the action of speaking happened when somebody can write what one says. And 'gloss' a way of interpreting or explaining something (Oxford Advanced Learner's Dictionary, 1995). Dictogloss itself can be defined as a process of explaining or interpreting spoken language.

Wajnrub (1990) defined dictogloss as a combine of both testing and teaching stimulates the motivation of learners. Rather than selection of specific grammatical features by teacher and the students obligate to practice them, the students identify their language problems and the teacher acts in response to their needs. Dictogloss value is in its interactive approach to language learning. In dictogloss text reconstruction promotes both the negotiation of meaning and form. It forces learners to stay actively engaged in the learning process with a cooperative effort. Adnan (2013) states that the advantages of dictogloss appear when students come to face their own strengths and weaknesses in English language use. While working their tasks, they find out what they do not know, and then they find out what they need to know.

The dictogloss strategy combines traditional teaching procedures such as warm-up, explicit vocabulary 
instruction and possibly grammar correction with a new type of meaning-based listening activity and cooperative learning. Language learning principles in dictogloss listening class: learner autonomy, focus on meaning and self a peer assessment, and cooperation among learners (Vasiljevic, 2010).

\subsection{Using Dictogloss in a Listening Context}

The Main function of stimulating learners to pay attention to target features, dictogloss can provide multiple opportunities to draw learners' attention to target linguistic forms in meaningful contexts. Dictogloss is wellresearched and theoretically driven focus-on-form techniques. They are similar in motivation learners to notice target linguistic features in meaningful contexts, and they mainly differ in the mode of instruction. The listener must have enough knowledge of language system like general knowledge of the world, listening requires the use of both systematic and schematic knowledge in order to interpret the discourse (Qin, 2008). Listening activities give the learner practice in identifying correctly combination of different sounds, and intonation patterns. It's important that the learners' proficiency increases meaning-based activities. Meaning-based activities can be divided into these wide categories: Activities that evaluate direct meaning comprehension, understanding of surface information of facts that are clearly stated in the input text, activities that measure reasoning meaning contain the hidden understanding and drawing interpretations from the input text (Daura, 2013).

\section{8 Stages of Dictogloss}

According to Wajnryb (1990), a dictogloss strategy should have four stages:

1. Preparation: facilitator introduces the topic and conducts a warming-up activity that contributes to the students' familiarization with the main ideas included in the text. At this time, the instructor introduces new vocabulary and explains how the activity works, and then he/she organizes students in small groups or pairs.

2. Dictation: The instructor reads the passage twice. At the first time students are instructed to listen without taking any note, and the second time they can. The text is supposed to be read at normal speed, identically both times.

3. Reconstruction: Learners share their notes and discuss how to reconstruct the text. The instructor monitors the activity but does not provide any type of input during this stage.

4. Analysis and correction: This stage could be adapted in two options. One option is for the instructor to write students' texts on the board and provide feedback. This part should be carried out in a sentence-by-sentence manner. The instructor can later provide the original version for students to review. The main aim is, to share the reconstructed texts and have students engage in error correction and analysis.

\subsection{Advantages of Dictogloss}

Nabei (1996) argues that students communicate in a content area of interest to them, but not about grammar only, while in study of (Swain, 1994) claimed that the dictogloss is a strategy in which students needed to communicate about grammar. Dictogloss was an effective language learning strategy since the strategy provides a context for negotiation. It offers several possible advantages over other models of teaching listening comprehension:

First: The dictogloss strategy is combining individual and group activities. Students listen and take notes individually and then work together to reconstruct the texts.

Second: In the dictogloss procedure Students' speaking time is significantly longer than in traditional teachercentered classroom. It facilitates the development of the learners' communicative competence.

Third: The reconstruction stage helps students to identify their strengths and weaknesses while they try out their hypotheses and subsequently (Vasiljevic, 2010).

\section{10 Cooperative Learning in Dictogloss}

Cooperative learning is the same meaning of collaborative learning. Cooperative learning has various principles. They have been put forward in the literature on cooperative learning (Kintsch, 1977).Working together to reach shared goals means the true cooperation. Individuals will seek outcomes that benefit not only themselves, but also all the members of the group in cooperative situations. Cooperative learning involves the instructional use of small groups so that students work together to increase their own, and each other's learning. Interaction shapes among students impacts their learning, their feelings toward the school, the teacher and other students, and their selfesteem. Dictogloss is an activity that naturally incorporates the elements of cooperative learning. Cooperative learning requires that students work together (typically in small groups of four to six) to learn information and carry out a range of tasks. The purpose is to improve peer group support and enrich peer instruction. The successful performance of a dictogloss activity includes features of cooperative learning and more. Students commonly work in groups of three or four, convey and learn new information while engaging in a task. In addition, peer support is the main step of dictogloss (Johnson and Johnson, 1994). However, cooperative learning principles informed in dictogloss strategy could be summed up in the following two points:

a. Heterogeneous Grouping: Instructor should form groups in which students are mixed on one or more of a number of variables including sex, social class, ethnicity, religion, personality, and language proficiency. 
Homogeneous grouping have a number of benefits, such as encouraging peer training, providing a variety of point of views, helping students come to know and like others different from themselves, and raising appreciation of the value of diversity.

b. Collaborative Skills: Collaborative skills applied in dictogloss showed by: asking for and giving reasons; disagreeing nicely and responding gently to disagreement; and encouraging others to participate and respond to encouragement to participate (Vasiljevic, 2010).

\subsection{Dictogloss and Learner Autonomy}

Learner autonomy involves learners having some choice as curriculum procedures. At the same time, feeling understanding and responsible for their own learning and for the learning of classmates. In dictogloss, students need to help each other to develop a mutual reconstruction of the text. Furthermore, it provides students with opportunities to see where they have done well and where they may need improvement (Jacobs and Small, 2003). The dictogloss procedure also promotes learners' autonomy when students are expected to help each other recreate the text rather than depend on the teacher to provide them with information. The analysis and correction stage enables the students to see where they have done well and where they need to improve. Students gain insights into their linguistic shortcomings and also develop strategies for solving the problems they have encountered (Vasiljevic, 2010).

Group autonomy: This principle encourages students to look to themselves for resources rather than depending on the teacher. The creation of small learning communities makes increased learner co-operation and participation. This insertion of 'democracy' into the environment of classroom allows learners to complement strengths and weaknesses of each other. It is very attractive for teachers to intervene either in a particular group or with the entire class in Step 4 of dictogloss, while students are working in their groups to reconstruct the text, and in Step 5, while students are comparing their text to the original. Teacher should resist this temptation; because they must trust the peer interaction to do many of the things they have felt responsible for themselves (Jacobs, and Small, 2003).

\subsection{Main Purpose of Dictogloss}

The main purpose of dictogloss listening class shows in the analysis and correction stage when students identify the problems with text comprehension. The reconstruction tasks ask students to use their language ability to put words into meaningful units. In that process higher ability students are likely to replace the word from the original text with their words. These ideas should be marked correct. Reconstruction checklist is provided, for each idea. Students are given an option of solely included, partially included or not included at all. The advantage of using reconstruction checklist is that students get immediate feedback on their performance (Daura, 2013).

Ur (1998) observes, unlike reading and writing assignments which can tolerate delayed feedback, it is essential that learners get feedback on their performance while what they have heard is still ringing somewhere on their mind and there is still a possibility of hearing it again. The fact that dictogloss has very specific outcomes makes it easier for students to evaluate their success. The teacher's job is to make that peer feedback is correct and to provide additional linguistic guidance if necessary by circulating among the groups. The teacher can observe and interact with a greater number of students and help them with the problems they may encounter with the language or the content in addition to linguistic feedback, the teacher could also discuss with the students on how interaction among group members could be modified to make it more effective. Learners correct and analyze their texts by writing their versions on the board and comparing this with the work of other groups. The students' versions are compared to the original text, one sentence at a time. Feedback through peer correction and discussion is then encouraged. Learner errors are noticed exposed and discussed.

\subsection{Previous Studies}

In this section, the researchers review some previous studies which are sequenced thematically according to the importance of the topic. The researchers display them in depth in order to benefit from their instruments, procedures, findings, implications, and suggestions.

Shak (2012) investigated children's attitudes towards dictogloss, a type of focus on form task designed to facilitate learners' understanding of the target form in a meaning-focused context. The study addressed whether children found dictogloss compatible with their interests, needs and motivation, and whether teachers found dictogloss appropriate in terms of their learning ability, teaches ability and task usefulness. A total of 78 children from three primary 5 classes in Brunei Darussalam took part in the study, and they were given attitude questionnaires at the end of each lesson. Findings based on the children's responses showed that there existed fluctuations in children's attitudes to the task during the grammar lessons, thus providing a strong implication that children's focus, through manipulation of task design and implementation, could be reinforced to process the target feature as they perform the task. The results also suggest that further classroom research is needed to find ways for teachers to adapt the dictogloss approach to their specific classes. 
Daura (2013) aimed to find the usefulness of the dictogloss in a second language learning context, twenty BA ED (Hausa) one hundred level students from the Language Arts section of the Ahmadu Bello University were used. Two texts were dictated to the students, one for each day. The result of the second task was recorded. The first exercise served as practice for the students to become familiar with the procedure. Although it is a new procedure, the results showed an improvement from the results of the first task. The students enjoyed the exercise and were willing to continue the next day even though the first results were not very good. Recommendations were given on how second language teachers could use dictogloss to their advantage for cooperative learning in listening comprehension classes.

Abbasian's and Mohammadi's (2013) study investigated the effect of dictogloss on Iranian EFL learners' general writing skill. The participants receiving a pretest and posttest were divided into equal groups in the form of experimental and control group, but only the former received task based instruction while the latter was exposed to the mainstream of controversial instruction. Going through rigorous and multiple statistical analyses such as data normality check, instrument validation and running mainly certain parametric statistics, the study revealed that the treatment affected positively the participants' general writing ability, and the effects on the organization and mechanics were positive, while content, usage and vocabulary dimensions of their writing were not much affected.

Gallego (2014) sought to determine which proficiency level might be most appropriate for the implementation of dictogloss and to gather learners' opinions regarding its usefulness and effectiveness. A total of 497 participants enrolled in novice-mid $(\mathrm{N}=275)$ and advanced-low $(\mathrm{N}=222)$ levels took part in the study. All participants engaged in two dictogloss strategies and completed a survey afterwards. Overall, results indicate that dictogloss was better received by advanced-low level students and that most students found it both useful and effective for learning.

Ahmadian, Amerian, and Lavasani (2015) investigated the effect of dictogloss as a cooperative learning strategy on the perceived self-efficacy of Iranian EFL learners in writing. There were 46 Persian speaking EFL learners participated in this study. Out of 46, 23 participants were taken as the experimental group and the other 23 as the control group. They were heterogeneous due to the cooperative nature of the study. The experimental group was exposed to the dictogloss strategy of cooperative learning, while the control group was exposed to the traditional strategy of writing instruction in TEFL writing classes. After 13 sessions of treatment, the self-efficacy in writing questionnaire was reapplied to both groups as the posttest. The participants' scores in the two groups were calculated and compared. The results revealed a difference between the two groups, indicating the effects of the dictogloss strategy of cooperative learning on self-efficacy in the writing of EFL learners.

Younis' and Bataineh's (2016) study investigated the potential effect of a proposed dictogloss -based program on Jordanian EFL tenth-grade teachers' writing instruction and on their students' writing performance. The participants were 20 Jordanian EFL teachers and 96 tenth-grade students selected from the public schools of AlKourah Directorate of Education in the second semester of the academic year 2015/2016. The teachers were trained on both the theoretical and practical aspects of dictogloss. The students were divided into an experimental group $(n=70)$ and a control group $(n=26)$. The former was taught through dictogloss while the latter was taught by the guidelines of the Teacher's Book. Statistically, significant differences were found between the teachers' performance on the pre and posttests, which can be attributed to the training. The findings further revealed statistically significant differences not only among the students of the experimental group on the pre and posttests but also in the overall writing performance of the experimental and control groups, in favor of the former.

Alsibai (2017) mainly attempted to investigate the effectiveness of one type of Focus on Form (FonF) language task (i.e.dictogloss) on female Translation University Students' grammatical competence. The objective of this study was to examine the effects of using the dictogloss task procedure on female Translation University Students enrolled in Grammar (1) at the College of Languages and Translation, King Saud University (KSU), Riyadh. The study also aimed to survey participants' attitudes and perceptions toward the application of dictogloss tasks. The researcher applied a quasi-experimental design model and survey study. The findings of the study demonstrated that in general, there was no significant statistical difference in verb-tense performance between the three groups' weekly test scores that were immediately administered after presenting dictogloss tasks, but most students, in both experimental groups, expressed satisfaction with the dictogloss task as a whole.

Dista, (2017) was an experimental one to use dictogloss as an Interactive Strategy with second Grade, year 8, students at Junior High School to try to improve the teaching-learning of Listening Comprehension with narrative texts. The study used two classes as the sample: the experimental group was taught using dictogloss, while the control group was taught by a standard strategy. To collect the data, tests and a questionnaire were used, and then the collected data was analyzed using SPSS. The results showed that the experimental group students taught using dictogloss, achieved significantly better scores in listening comprehension. Moreover, the results from the questionnaires indicated that almost all the students (93\%) responded positively towards the use of dictogloss since it effectively improved their listening comprehension.

Azmi (2017) examined the use of the dictogloss strategy for teaching-learning listening. The objective of this study was to see if this strategy would be an efficient way to teach-learn English listening with 12th grade students 
from SMAN 5, Banda Aceh. The study used experimental study strategies with $(\alpha=0.05)$. The sample for this study was 32 students from the 12th grade at SMAN 5 Banda Aceh. These students were grouped into an experimental group and a control group. Before the treatment, each group was given a pretest; and after the treatment a posttest was again administered to both groups. The pretest and the posttest each consisted of ten questions which the students had to answer after listening to a text. The data was analyzed statistically. All the data was normal and homogenous. From the t-test, the critical area 27 was -2.03 to +2.03 . The t-test value from the posttest between the experimental and the control groups were 0.92 which was within the critical area. Hence the null hypothesis was rejected and the alternative hypothesis was accepted which meant that dictogloss was found to be an effective strategy to use for improving the listening ability of 12 th grade students.

Taheri and Taki (2017) aimed at investigating the effect of dictogloss on EFL learners' listening comprehension as well as on their use of metacognitive listening strategies with a focus on the effects on male and female learners. A total number of 50 female and male Iranian EFL learners, aged between 12 and 15 years old, at the intermediate proficiency level in a private language school in Iran were selected and randomly assigned to experimental and control groups with 25 male and female learners in each group. Dictogloss was employed to teach the learners in the experimental group for an instruction period of 12 sessions. Participants' listening comprehension was determined through a pre/posttest. The data collected were submitted to the t-test and results revealed significant improvement in the experimental group's listening comprehension with no significant difference between male and female learners. Finally, the results showed that the listeners in the experimental group made noticeable gains in their choice of metacognitive strategies through using the dictogloss strategy.

Muthmainnah's and Asrifan's (2018) study was to find out whether or not the use of English dictogloss technique was able to improve listening comprehension of the second year students of SMP Negeri. This research employed a quasi-experimental method that applied experimental and control groups. The population of this research was eighth-grade students of SMP Negeri in 2016-2017 academic years. A total number of population was 48 students are taken a sample by using total sampling technique. The instrument that used in this research was listening comprehension test. The result of the data analysis showed the mean score of the experimental group got the mean score (77.0) and while the control group gained mean score (63.3) this showed that there was significant difference between the students who were taught by using English dictogloss technique and those who were using traditional methods. The alternative hypothesis was accepted and the null hypothesis (H0) was rejected. It can be concluded that the students had good listening comprehension achievement by using English dictogloss.

Quiroz, Ledesma, and Calahorrano (2018) aimed to investigate the impact of using note-taking, dictogloss, and dictation to improve listening comprehension. It is an experimental investigation in terms of nature and strategy. The statistical population is the students of an English university institute within an academic semester. The data collection tool was a researcher team-made questionnaire and interviews. The results showed that the lack of listening teaching and insufficient listening habits were the cause of limited listening skills in the students. These results supported the need to apply this study. The treatment was given to 15 pre-intermediate English students (the experimental group). It consisted of the application of listening strategies based on strategy (notetaking, dictogloss, and dictation). Data was gathered by means of a pretest and a posttest.

The means, standard deviations and the t-test were used to analyze the data and test the hypotheses. The results showed that the application of note-taking, dictogloss, and dictation increase significantly students listening comprehension.

Ba'lousha's (2019) study investigated the impact of dictogloss strategy on ninth graders' critical reading, adopting the quasi-experimental approach for one experimental group consisted of 35 female students. The dictogloss strategy was applied on students for 10 sessions within 2 weeks; then the data were collected via a critical reading posttest. After comparing the differences between the pre and the posttests, findings suggest that there is a wide effect of dictogloss strategy on 9th graders' critical reading, which leads to recommend applying dictogloss in teaching English reading skills in the classes and to pay more attention to critical reading skills improving.

All of the previous studies investigate the effectiveness of using dictogloss strategy. They are containing different investigated English language skills. Some of them investigate the employing of dictogloss method in writing skill such as Abbasian, and Mohammadi (2013), Ahmadian Amerian, and lavansani (2015) and Younes and Bataina(2016). One study talks about the impact of dictoglos in reading which is Baloush's(2019). Shak's (2012).Daura's (2013), and Alsibai's (2017) studies aim to investigate the effect of dictogloss on form. Quiroz's, Ledesma's, and Calahorrano's (2018), Muthmainnah's and Asrifan's (2018) Taheri's and Taki's (2017) and Azmi's (2017) studies are almost consistent with the present study in testing the employing of dictogloss strategy in listening skill. Also, Younes's and Bataina's (2016) study is correspondent with the present study; both studies were conducted in Jordan.

This study is different from the previous studies for its expanding on theoretical aspect side by side with the experimental method and from the place and time of study applying. The present study works to link listening skill with dictation, while using dictogloss strategy. Few studies in Jordan mention this topic and tested it as a new 
strategy that is not mentioned in the preparation notebook strategies of EFL teachers in Jordan. This study is also special since its statement of the problem expressing the disadvantages of traditional dictation.

\section{Methodology}

This chapter presents approaches of the study: the study design, participants, instrument, validity and reliability of the instrument, procedures and data analysis.

\subsection{Study Design}

The study used quasi-experimental strategy which was designed to answer the question of the study and to prove the hypothesis. The researchers aimed to find out the effectiveness of dictogloss strategy in which texts were played or spoken to enhance students' listening skill. The experimental method is a systematic scientific approach to conduct study in which the researchers manipulate one ore more variables, and measure any change in other variables.

\subsection{Participants}

The participants of the study consist of 74 EFL ninth grade students whose native language is Arabic. They are all about 15 years old who have started learning English in their first grade. Two classes: 9-A and 9-B at Ain AlBaida secondary schools for girls were chosen as the sample of the study. There were 37 students in section A and 37 in section B. The sample was chosen randomly, section A was assigned as experimental group and section B was assigned as control group. Table 1 below shows the distribution of the participants according to their group and grade.

Table 1. Distribution of the Participants of the Study

\begin{tabular}{|l|l|l|}
\hline Grade & Group & Number \\
\hline Ninth grade A & Experimental & 37 \\
Ninth grade B & Control & 37 \\
Total & & 74 \\
\hline
\end{tabular}

\subsection{Study Instrument}

An achievement listening test (4 paragraphs chosen from the Student's Book) was used to collect the data. In this test, students were asked to listen to the teacher and then they had to answer questions based on the text they heard. There was a pretest and a posttest. Both tests were designed to evaluate the students' ability to understand the given texts. The students were asked to answer 4 questions after they had heard each paragraph for two times.

\subsection{Test Validity}

The validity of the test was obtained by 10 referees: 3 university professors, 3 English language supervisors and 4 experienced EFL teachers, whose remarks were taken into account in the final version of the test.

\subsection{Test Reliability}

The reliability of the test was established by administering it to a sample of 27 students who were excluded from the sample of the study. Pearson correlation coefficient for the test calculation was found to be $81 \%$ which is suitable for the purpose of the present study.

\subsection{Study Variables}

- Independent Variables: dictogloss strategy and conventional methods.

- Dependant Variable: degree of the improvement of the students' performance in listening skill.

\subsection{Procedures of the study}

To accomplish the objectives of the study, researchers did the following:

- Reviewing related literature about dictogloss strategy and listening skill.

- Constructing theoretical framework about the variables of the study; dictogloss strategy as an independent variable and students' achievement in listening skill as dependant variable.

- Designing an achievement test which examines listening skill.

- Defining the sample (randomly) to represent the subject of the study.

- Implementing a pretest on the two groups (experimental and control) to gain equivalence.

- Employing dictogloss strategy in teaching listening for the experimental group.

- Administering the posttest on both groups and collecting data.

- Analyzing and processing the collected data.

- Providing some recommendations. 


\subsection{Data Analysis}

After collecting the data, it was processed into the computer using (SPSS) program. The analysis process went as follows:

- Calculating means, standard deviations, and analysis of covariance for the pretest to be sure of the groups' equality.

- Calculating means, standard deviations and t-test to answer the question of the study.

\section{Findings of the Study}

The stages of dictogloss yielded significant results which support the objective of the study. The results of the impact of dictogloss strategy on listening skill are totally presented in this chapter. These results are analyzed by means of pretest and posttest. The findings are presented and discussed with regard to the question of the study.

To make sure that the two groups (experiment and control) are equivalent in the listening skill, a pretest was administered before starting the experiment. Table 2 shows t-test and pretest results for the means of scores due to groups. There is no significant differences at the level of $(\alpha=0.05)$ between the experimental and control groups on the pretest.

Table 2. Results of Experimental and Control Groups on Pretest

\begin{tabular}{|c|c|c|c|c|c|c|c|c|c|}
\hline \multirow{3}{*}{$\begin{array}{l}\text { Levine's Test for } \\
\text { Equality of Variances }\end{array}$} & \multicolumn{9}{|c|}{ T-test for Equality of Means } \\
\hline & \multirow[t]{2}{*}{$\mathrm{F}$} & \multirow[t]{2}{*}{ Sig } & \multirow[t]{2}{*}{$\mathrm{T}$} & \multirow[t]{2}{*}{ Df } & \multirow[t]{2}{*}{$\begin{array}{ll}\text { Sig. } & 2 \\
\text { tailed. } & \end{array}$} & \multirow[t]{2}{*}{$\begin{array}{l}\text { Mean } \\
\text { Dif. }\end{array}$} & \multirow[t]{2}{*}{$\begin{array}{l}\text { Std. } \\
\text { Error } \\
\text { Dif. }\end{array}$} & \multicolumn{2}{|c|}{$\begin{array}{l}95 \% \text { Confidence Interval } \\
\text { of the Difference } \\
\text { Lower } \\
\text { Upper }\end{array}$} \\
\hline & & & & & & & & Lower & Upper \\
\hline $\begin{array}{ll}\text { Equal } & \text { Variances } \\
\text { Assumed } & \end{array}$ & .66 & .68 & .329 & 72 & .74 & .51 & 1.55 & 3.62 & 2.59 \\
\hline
\end{tabular}

The question of the study seeks potentially statistically significant differences at the level of $(\alpha=0.05)$ between the mean scores of the students in the experimental and control groups on the pre and posttests which can be attributed to the teaching strategy (conventional or dictogloss). To answer the question, means and standard deviations were calculated as shown in Table 3.

Table 3.

Means and Standard Deviations of Pre and Posttests

\begin{tabular}{|l|l|l|l|}
\hline Group & Pretest & Posttest \\
\hline Experimental & Means & 26.45 & 27.13 \\
\hline & Standard Deviations & 6.39 & 6.26 \\
\hline Control & Means & 24.89 & 25.08 \\
\hline & Standard Deviations & 6.49 & 6.70 \\
\hline
\end{tabular}

Table 3 shows a noticeable difference between the mean scores of the students in the experimental group on the pre and posttests. When comparing the means and standard deviations of the experimental group on the pretest (26.45 - 6.39) with the means and standard deviations on the posttest $(27.13-6.26)$, it signal gains in the achievement of the students on the posttest. Table 3 reveals also an observed difference between the mean scores of the experimental and control groups on the posttest (27.13 vs. 25.8), the difference is in favor of the experimental group.

To determine the potential significance of these differences between the means, after eliminating the differences of the students' performance on the pretest, one way ANCOVA was used, as shown in Table 4. Table 4. Presents One way ANCOVA on the Posttest

\begin{tabular}{|l|l|l|l|l|l|l|}
\hline Source & Sum of Squares & Df & Mean Squares & F & Sig. & $\begin{array}{l}\text { Partial Eta } \\
\text { Squared }\end{array}$ \\
\hline Corrected Model & 2927.072 & 2 & 1463.536 & 570.741 & .000 & .941 \\
Intercept & 4.697 & 1 & 4.697 & 1.832 & .180 & .025 \\
Pretest & 5.005 & 1 & 5.005 & 1.952 & .167 & .027 \\
Group & 2849.018 & 1 & 2849.018 & 1111.043 & .000 & .940 \\
Error & 182.063 & 71 & 2.564 & & & \\
Total & 53550 & 74 & & & & \\
Corrected Total & 3109.135 & 73 & & & & \\
\hline
\end{tabular}

Table 4 reveals a statistically significant difference at the level $(\alpha=0.05)$ of the students' performance on the posttest due to the teaching method (dictogloss strategy). 


\subsection{Discussion of Findings}

The primary aim of this study is to explore the effect of dictogloss strategy on the students' listening skill. In order to answer the question of the study, data were collected and analyzed using ANCOVA. The answer was statistically positive. Results suggest that there is a significant difference between the mean scores of the experimental and control groups in favor of the experimental. The findings of the present study are totally consistent with Jacobs and Small (2003) who confirmed the positive effect of dictogloss strategy on language skills. The findings shown in Table 3 and Table 4 indicate remarkable improvement in the students' performance in listening skill. This improvement could be attributed to the systematic employment of dictogloss strategy in the classroom. The mean scores of these items indicate that the teachers implemented the procedures of a creative teaching method (dictogloss) frequently. Teacher presents the material in a logical sequence; students express themselves orally and in writing as well as discuss the texts individually and then in groups before writing their final version.

As a result, students' performance in listening skill is positively affected. The performance of the students in the experimental group could be related to the students who enjoy the activities throughout the treatment and engage themselves effectively in it. Besides, the findings of the present study advocate the theory proposed by Wajnaryb (1990). Wajnaryb argues that dictogloss gives students more accurate understanding of English grammar more than other approaches, and it consequently leads to higher accuracy of language use. Compared to the other traditional methods of teaching grammar, the value of dictogloss strategy is in its interactive way to language learning. Text reconstruction fosters both negotiation of meanings and forms of the language. It is actually a cooperative treatment which forces learners to stay actively engaged in the teaching-learning process. The findings of this study are also consistent with the results of the study which was conducted by Abdul Arif (2013), who assured the efficacy of dictogloss strategy on different language skills, especially listening skill.

\subsection{Conclusion}

The present study concludes that the implementation of dictogloss strategy in teaching listening skill can increase the students' achievement in the English listening skill. There was a significant improvement shown by the students who were taught by dictogloss strategy when compared to those who were taught by conventional methods. Using dictogloss strategy was efficient since the students learn how to do reconstruction and inquiry processes when they rebuild texts based on their own understanding and using their own words. The study proved that the students gained higher marks in the posttest more than that of the pretest. This means that the significance was in favor of the students who used dictogloss strategy. So, we could say that the use of dictogloss is highly efficient in teaching listening skill for the ninth graders in Jordan.

\section{Recommendations}

In the light of the findings of the present study, the researchers recommend the following:

* Teachers should be trained to incorporate dictogloss strategy into their instructional practices inside the EFL classrooms.

* Teachers should emancipate themselves from conventional methods of teaching to venture into supplementing their practices with some creative strategies as dictogloss strategy.

* Teachers of other subjects could also use dictogloss strategy after modifying it to become convenient to the nature of the subject they teach.

\section{References}

Abbasian, G.,\& Mohammadi, M. (2013), “The Effectiveness of Dictogloss in Developing General Writing Skill of Iranian Intermediate EFL learners", Journal of Language Teaching and Research 4(6), 1371-1380.

Abdel-Al, A. (2002), "The Effect of Strategy-Based Instruction Program on Developing EFL Listening Comprehension Skills", PhD Thesis,Dissertation, center for English language Teacher Education, Warwick University.

Adam, A. (2013), "Improving Students Listening Comprehension of Grade X Students of SMA Nigeria", $E$ Journal Bahasantodea, 1 (1), 49-60.

Adnan, A. (2013), "The Use of Dictogloss Strategy in Teaching Listening a Hortatory Exposition Text at Senior High School”, Journal of English Language Teaching, 2 (1), 50-58.

Ahmadian, M., Amerian, M., \& Lavasani, E. (2015), "The Effect of the Dicto-gloss as a Cooperative Learning Strategy on EFL Learners' Self efficacy in Writing", Journal of Language Teaching and Study, 6 (6), 13571364.

Alsibai, D. (2017), "Using Dictogloss Tasks: Attention to Form in a Collaborative Classroom Activity with Female Translation Students at King Saud University", Arab World English Journal (AWEJ), 8(2), 333 - 348.

Anderson, J. (2002), "The Role of Metacognition in Second Language Teaching and Learning”, ERIC Digest, 3(2), 3-4.

Arif, A. (2013), “The Effectiveness of Dictogloss to Teach Writing Skill Viewed from Students' Risk-Taking”, 
MA Thesis, At The English Education Department of Stkip-Pgri Pontianak.King Saud University.

Azmi, V. (2017), "Using Dictogloss Strategy to Enhance Listening Ability”, English Education Journal (EEJ), $8(1), 55-66$.

Ba'lousha, I. (2019), “The Impact of Dictogloss Strategy on Ninth Graders' Critical Reading”, IUG Journal of Educational and Psychology Sciences, 27 (03), 61-78.

Bataina, R.andYounes,R. (2016), "The Effect of Dictogloss on Jordanian EFL Teachers' Instructional Practices and Students' Writing Performance”, International Journal of Education and Training, 2(1), 1-11.

Buck, G. (2001), “Assessing Listening”, Cambridge, Cambridge University press.

Carter,R. \& Nunan,C. (eds.) (2001), "The Cambridge Guide to Teaching English to Speakers of Other Languages", Cambridge, C.U.P.

Cross, D. (1998), “Teach English”, Oxford, Oxford University Press.

Daura, R. (2013), "Using Dictogloss as an Interactive Method of Teaching”, Advances in Language and Literary Studies, 4(2), 112-116.

Dista, D. (2017), “Using Dictogloss to Improve Listening Comprehension”, English Education Journal, 8(2), 149163.

Gallego, M. (2014), “Second Language Learners' Reflections on the Effectiveness of Dictogloss S: A MultiSectional, Multi-Level Analysis", Studies in Second Language Learning and Teaching,

4 (1), 33-50.

Hwaider, M. (2017), "Problems of Teaching Listening Skill to Yemeni EFL Learners", International Journal of Scientific and Study Publications, 7(6), 140-148.

Jacobs, G.and Small, J. (2003), "Combining Dictogloss and Cooperative Learning to Promote Language Learning", Reading Matrix, 3(1), 185-194.

Johnson, D., \& Johnson, T. (1999), "What Makes Cooperative Learning Work, Cooperative Learning”, Japan: JALT Applied Materials.

Kintsch, W. (1977), "Memory and Cognition", US: John Wiley and Sons.

Kurita, T. (2012), "Issues in Second language Listening Comprehension and the Pedagogical Implications", Accents Asia, 5 (1), 30-44.

Mendelsohn, D. (1998), “Teaching Listening”, Annual Review of Applied Linguistics, 18(1), 81-101.

Muthmainnah, S., Asrifan A., Al Yakin, A., \& Sahabuddin, C. (2018), "The Use of Dictogloss Technique on Elt Classroom: An Experiment Study of Students Listening Comprehension”, The 65th TEFLIN International Conference, 65(1), 212-226.

Nabei,T. (1996), “Dictogloss: Is It An Effective Language Learning Strategy?”, Working Papers in Educational Linguistics, 12 (1), 59-74.

Qin, J. (2008), "The Effect of Processing Instruction and Dictogloss Tasks on Acquisition of the English Passive Voice”, Language Teaching Research, 12(1), 61-82.

Quiroz, M., Ledesma, V., \& Calahorrano, L. (2018), “The Impact of Using Note-Taking, Dictogloss, and Dictation to Improve Listening Comprehension English Language", Revista Científica MQR investigar, 2(2), 89-109.

Renukadevi,D. (2014), "The Role of Listening in Language Acquisition; the Challenges and Strategies in Teaching Listening", International Journal of Education and Information Studies, 4 (1), 59-63.

Rixon, S. (1986), "Developing Listening Skill”, London: Macmillan Publisher Limited.

Shak, J. (2012), "Children Using Dictogloss to Focus on Form", Reflections on English Language Teaching, 5(2), 47-62.

Swain, M. (1994), "Three Functions of Output in Second Language Learning", Principles and Practice in the Study of Language, 109(140), 125-144.

Taheri, M., \& Taki, S. (2017), "The Effect of Dictogloss on Listening Comprehension: Focus on Metacognitive Strategies and Gender", International Journal of Applied Linguistics and English Literature, 6(7), 23-29.

Ur, p. (1998), “Teaching Listening Comprehension", UK, Cambridge University Press.

Vasiljevic,Z. (2010), "Dictogloss as an Interactive Strategy of Teaching Listening Comprehension to L2 Learners", English Language Teaching, 13(1),191-210.

Wajnryb, R. (1990), “Grammar Dictation”, Oxford, Oxford University Press.

Younis, R., \& Bataineh, R. (2016), “To Dictogloss or not to Dictogloss: Potential Effects on Jordanian EF Learners' Written Performance1", Apples - Journal of Applied Language Studies, 10 (2), 45-62. 